\title{
ANALISIS BEBAN KERJA PERAWAT PELAKSANA DI INSTALASI RAWAT INAP RSUD X KOTA BENGKULU
}

\section{An Analysis Of Workload Of Nurse PractitionerAt Inpatient Care Facility Of X Public Hospital In Bengkulu}

\author{
Riska Yunita, Rahmi Fahmi, Leni mardawati \\ Program Studi S2 Keperawatan UniversitaAndalas Padang \\ riska.yunita1985@gmail.com.
}

\begin{abstract}
ABSTRAK
Perawat yang bekerja di rumah sakit mengalami beban kerja yang tinggi. Begitu juga perawat yang bekerja di rumah sakit Asi tenggara, termasuk Indonesia. Perawat yang bekerja di RSUD X Kota Bengkulu juga mengalami beban kerja yang tinggi, sehingga waktu istirahatnya digunakan untuk melayani pasien dan keluarga. Tujuan penelitian adalah menganalisis beban kerja perawat pelaksana di Instalasi Rawat Inap RSUD X Kota Bengkulu. Jenis penelitian ini deskriptif dengan cara observasi. Responden dalam penelitian dengan melibatkan 37 perawat di Instalasi Rawat Inap Rumah Sakit X Kota Bengkulu. Hasil penelitian didapatkan beban kerja perawat pelaksana RSUD X Kota Bengkulu tahun 2017 sebagian besar produktif sebanyak 86,5\%. Waktu rerata keperawatan langsung rerata 186,51 menit (3 jam 7 menit). Waktu rerata keperawatan tidak langsung rerata 165,43 menit (2 jam 46 menit). Waktu rerata pendidikan kesehatan rerata waktu 10,38 menit. Waktu kegiatan pribadi rata-rata waktu 56,06 menit. Disarankan bagi bidang keperawatan perlu dipertimbangkan pengelolaan tenaga perawat agar beban kerja lebih seimbang dengan pengaturan shif waktu kerja. Menetapkan penghitungan jumlah perawat yang lebih tepat dan juga meningkatkan observasi terhadap kegiatan perawat pelaksana dalam memberikan pelayanan keperawatan.
\end{abstract}

Kata Kunci : Beban Kerja, Kegiatan Langsung, Kegiatan Tidak langsung, Pendidikan Kesehatan

\section{ABSTRACT}

Nurses working in the hospital have a high workload. So do nurses who work in hospitals Southeast Asia, including Indonesia. Nurses who work in RSUD X Bengkulu City also experienced a high workload, so the rest time is used to serve patients and families. The purpose of this study is to analyze the workload of nurses in the Inpatient Installation of RSUD X of Bengkulu City. This type of research is descriptive by means of observation. Respondents in the study involving 37 nurses at the Installation Hospital X Bengkulu City. The result of the research shows that the workload of nurse of RSUD X Bengkulu in 2017 is mostly productive as much as 86.5\%. Average direct nursing time averages 186.51 minutes ( 3 hours 7 minutes). The average indirect nursing time is 165.43 minutes (2 hours 46 minutes). The average health education time averaged 10.38 minutes. Average personal activity is of 56.06 minutes. It is advisable for the nursing field to consider the management of nurses to workload more balanced with shifting work time. Establish a more accurate counting of the nurses and also increase observation of nursing activities in providing nursing service.

Keywords: Workload, Direct Nursing, Indirect Nursing, Health Education, Nursing Nurses

\section{PENDAHULUAN}

Menurut UU No 44 tahun 2009 dinyatakan bahwa rumah sakit adalah institusi pelayanan kesehatan yang menyelenggarakan pelayanan kesehatan perorangan secara paripurna yang menyediakan pelayanan rawat inap, rawat jalan dan gawat darurat. Rumah sakit sebagai tempat pelayanan publik dalam melayani masyarakat, juga ditunjang dengan ketersediaan sumber daya manusia (SDM). SDM yang memiliki pengetahuan yang baik sebagai tenaga medis diharapkan mampu menangani berbagai masalah kesehatan (Nursalam, 2002).

Keberhasilan dalam memberikan pelayanan di rumah sakit melibatkan sumber daya manusia. Salah satu sumber daya yang terlibat secara langsung dalam pemberian pelayanan kepada pasien adalah perawat. Perawat adalah sumber daya yang paling dominan diantara sumber daya manusia lainnya. Proporsi perawat diperkirakan sekitar 75\%. Presentase yang begitu besar dalam pelayanan keperawatan, tenaga keperawatan dapat dikatakan 
sebagai aset bagi rumah sakit dalam meningkatkan mutu kualitas pelayanan kesehatan. Selain itu pelayanan keperawatan memberikan pelayanan kepada pasien selama 24 jam (Umansky, 2016). Pelayanan keperawatan diberikan dalam bentuk asuhan keperawatan yang profesional. Oleh karena itu manajer perawat harus menyimbangkan antara jumlah perawat yang ditugaskan dengan dan beban kerja perawat. Dalam mencapai keseimbangan ini perawat harus mampu merencanakan secara baik agar jumlah perawat yang mencukupi dalam memberikan asuhan keperawatan terhadap pasien. Pasien di rumah sakit cenderung mengalami variasi baik dari kondisi kesehatan maupun jumlah pasien. Maka perkiraan beban kerja sangat penting untuk diperhatikan (Gillies, 1996).

Beban kerja perawat yang tinggi akan memberikan dampak terhadap kualitas layanan, terjadinya komunikasi yang buruk antar perawat dan pasien, kegagalan kolaborasi antar perawat dan dokter. Ketidakpuasan kerja perawat, juga dapat menimbulkan stress, kebosanan kejenuhan, kelelahan mental, dan menurunnya efektifitas kerja. Adapun dampak psikologis akibat beban kerja yang tinggi adalah stress, ketegangan dan kebosanan atau kejenuhan dan ada pula perasaan jengkel (Qadarsyah, 2006).

Menurut Gaudine (2000) ada beberapa dampak beban kerja yaitu: 1) menurunya penggiatan pusat saraf yang disertai dengan munculnya perasaanperasaan kelelahan, 2) keletihan, 3) kelesuan dan berkurangnya kewaspadaan, 4) kebosanan dalam kerja rutin sehari-hari karena tugas atau pekerjaan yang terlalu sedikit mengakibatkan kurangnya perhatian pada pekerjaan sehingga secara profesional membahayakan pekerjaan. Perawat yang diberi beban kerja berlebihan dapat berdampak kepada penurunan tingkat kesehatan, motivasi kerja, kualitas pelayanan keperawatan, dan kegagalan melakukan tindakan pertolongan terhadap pasien dan dikatakan bahwa peningkatan beban kerja perawat dalam menangani 4 orang pasien menjadi 6 orang mengakibatkan peningkatan sebesar $14 \%$ kemungkinan terjadinya kelalaian atau bahkan kemandirian pasien yang dirawat (Pesant, 2016).

Alghamdi (2016) mengatakan bahwa rata-rata di setiap rumah sakit di seluruh dunia masih mengalami kekurangan perawat dan beban kerja yang meningkat serta meningkatnya tuntutan kerja. Hasil penelitian lainnya menyatakan bahwa perawat yang bekerja di rumah sakit di Asia Tenggara termasuk Indonesia memiliki beban kerja berlebihan dan beban tugas non keperawatan.

Beban kerja adalah frekuensi ratarata masing-masing jenis pekerjaan dalam jangka waktu tertentu, dimana dalam memperkirakan beban kerja dari organisasi dapat dilakukan berdasarkan perhitungan atau pengalaman (peraturan pemerintah RI nomor 97 tahun 2000). Beban kerja perawat adalah seluruh kegiatan/ aktivitas yang dilakukan oleh seorang perawat selama bertugas di suatu unit pelayanan keperawatan (Marquis dan Huston, 2000).

Beban kerja dalam pelayanan keperawatan dapat dilihat dari aspek-aspek seperti tugas-tugas yang dijalankan berdasarkan fungsi utama, begitupun tugas tambahan yang dikerjakan, jumlah pasien yang harus dirawat, kapasitas kerjanya sesuai dengan pendidikan yang ia peroleh (Ilyas, 2000). Waktu kerja yang digunakan untuk mengerjakan tugasnya sesuai dengan jam kerja yang berlangsung setiap hari, serta kelengkapan fasilitas yang dapat membantu perawat menyelesaikan kerjanya dengan baik (Irwandy, 2007). Dalam menentukan beban kerja perawat yang perlu dipertimbangkan jumlah klien yang dirawat, tingkat ketergantungan, frekuensi tindakan perawat yang dibutuhkan klien, pengukuran keperawatan langsung, keperawatan tidak langsung dan pendidikan kesehatan (Arwani, 2006). Keperawatan langsung adalah perawatan yang diberikan perawat pada pasien yang dihubungan secara khusus dengan fisik 
dan psikologis pasien. Perawatan tidak langsung merupakan kegiatan yang dilakukan atas nama pasien tetapi tanpa kehadiran pasien bersama perawat yang berhubungan dengan lingkungan pasien atau finansial dan kesejahteraan sosial pasien. Sedangkan pendidikan kesehatan mencakup semua usaha perawat untuk memberitahu dan memotivasi pasien dan keluarganya menyangkut perawatan selama di rumah sakit (Gillies, 1996).

RSUD X Kota Bengkulu merupakan rumah sakit umum daerah milik pemerintah daerah kota Bengkulu yang mempunyai 19 instalasi rawat jalan, 22 ruang rawat inap dan mempunyai 4 rawat khusus dengan jumlah 320 perawat pelaksana dan jumlah tempat tidur untuk ruangan rawat inap 249 tempat tidur. Indikator mutu pelayanan rawat inap pada tahun 2016 didapatkan Bed Occupancy Rate 54.53\% (60-80\%), Bed Turn Over 53.29/hari (40-50\%), Average Leght of Stay 2.91/hari (6-9\%). Turn Over Internal $3.80 \%$ hari (1-3\%), Gross Death Rate (GDR) 59.83\% ( $\leq 0.24 \%)$, dan Net Death Rate (NDR) 31.78\% (>2.5\%).

Berdasarkan studi pendahuluan yang dilakukan pada ruang rawat inap melati (penyakit dalam) dan ruang rawat seruni (bedah) dengan jumlah pasien pada masing-masing ruangan lebih kurang 50 orang pasien. Perawat yang bertugas pada shif pagi 7 orang dengan perawat pelaksana 4 orang, pada shif sore 4 orang perawat dan shif malam sebanyak 4 orang perawat juga. Wawancara dengan 5 perawat didapatkan bahwa perawat mengatakan mereka mengalami beban kerja yang berat. Keperawatan lanmgsung yang diberikan perawat kepada pasien antara lain membersihkan luka pasien, mengganti balutan pasien, mengganti cairan infuse pasien, memberikan obat melalui cairan infuse kepada pasien, melakukan EKG kepada pasien, pemeriksaan tanda-tanda vital setiap pasien. Sedangkan keperawatan tidak langsung antara lain mendampingi dokter melakukan visite, menerima pendelegasian pengobatan pasien, kegiatan administrasi. Disamping itu perawat juga sering menjelaskan kondisi pasien baik kepada pasien maupun keluarga pasien. Sehingga waktu yang seharusnya digunakan untuk istirahat dan makan tersita dengan tetap melayani pasien dan keluarga.

Berdasarkan uraian di atas maka peneliti tertarik untuk melakukan penelitian tentang "Analisis beban kerja tenaga perawat di instalasi rawat inap RSUD X Kota Bengkulu”.

\section{METODE PENELITIAN}

Penelitian ini merupakan penelitian kuantitatif dengan menggunakan tehnik observasi. Populasi dalam penelitian ini adalah seluruh perawat pelaksana yang bekerja di RSUD X rawat inap ruangan melati dan seruni RSUD X Kota Bengkulu yang berjumlah 38 orang. Jumlah sampel seluruh (total sampling) perawat pelaksana di ruang rawat inap ruangan melati dan seruni sebanyak 38 orang.

\section{HASIL DAN PEMBAHASAN}

Tabel 1. Distribusi Frekuensi Karakteristik Perawat Pelaksana berdasarkan Jenis Kelamin, Tingkat Pendidikan, dan Status kepegawaian di RSUD X Kota Bengkulu Tahun 2017 (n=37)

\begin{tabular}{clcc}
\hline No & Karakteristik & $\mathrm{F}$ & $\%$ \\
\hline 1 & Jenis Kelamin & 24 & 64,9 \\
& a. Perempuan & 13 & 35,1 \\
& b. Laki-laki & & 27,0 \\
& Tingkat Pendidikan & 10 & 62,2 \\
& a. DIII Keperawatan & 23 & 10,8 \\
& b. S1 Keperawatan & 4 & 67,6 \\
& c. Profesi Ners & & 32,4 \\
\hline
\end{tabular}


Berdasarkan Table 1. diketahui bahwa karakteristik perawat pelaksana di RSUD X Kota Bengkulu adalah lebih dari separuh berjenis kelamin perempuan $(64,9 \%)$, lebih dari separuh berpendidikan S1 keperawatan (62,2\%), lebih dari separuh dengan status kepegawaiannya adalah PNS (67,6\%).

Karakteristik berdasarkan jenis kelamin dalam penelitian sejalan dengan penelitian Akde (2015) bahwa lebih dari separuh perawat pelaksana di Rumah Sakit Islam Kendal berjenis kelamin perempuan (79,2\%). Begitu juga penelitian Imran (2013) diketahui bahwa lebih dari separuh perawat pelaksana di RSUD Raden Matther Jambi berjenis kelamin perempuan (67,6\%). Maka perawat pelaksana di rumah sakit lebih didominasikan oleh jenis kelamin perempuan. Menurut Tawi dalam Intan (2016), keperawatan muncul dari peran perspektif perempuan lebih banyak dari laki-laki.

Profesi keperawatan pada umumnya didominasi oleh kaum perempuan karena perempuan dalam memberikan pelayanan keperawatan sangat teliti, sabar dan identik dengan rasa keibuan. Karakteristik berdasarkan tingkat pendidikan sejalan dengan penelitian Imran (2013) menemukan bahwa lebih dari separuh perawat pelaksana berpendidikan S1 keperawatan (68,8\%). Begitu juga penelitian Intan (2016), didapati bahwa lebih dari separuh tingkat pendidikan perawat pelaksana di rumah sakit PKU Muhammadih Yogyakarta adalah S1 keperawatan (90,8\%). Dalam sebuah pendidikan terdapat proses belajar yang menghasilkan pengetahuan, kepercayaan dan sikap tertentu. Tingkat pendidikan seseorang akan berpengaruh terhadap pola pikir dalam mempertimbangkan sesuatu. Disamping itu makta (2013) jika perawat diberi kesempatan untuk berkembang melalui pendidikan dan pelatihan ataupun promosi jabatan maka kinerja perawat akan meningkat.

Karakteristik berdasarkan status kepegawaian juga sejalan dengan penelitian Ake (2014) di instalasi rawat inap C RSUP Prof. Dr. R.D. Kandou manado yaitu lebih dari separuh status kepegawaian perawat pelaksana adalah PNS (68,7\%). Wirdah (2015) juga menemukan di dalam penelitiannya bahwa lebih dari separuh perawat pelaksana di Rumah Sakit Banda Aceh memiliki status kepegawaian PNS (68,1\%). Berdasarkan hal tersebut, peneliti berasumsi bahwa perawat PNS telah memiliki status, pangkat ataupun golongan yang jelas di rumah sakit, memiliki jaminan sosial berupa asuransi kesehatan serta tunjangan jaminan sosial berupa asuransi kesehatan serta tunjangan lain di luar gaji pokok.

Table 2. Distribusi Karakteristik Berdasarkan Umur dan Lama Bekerja Perawat Pelaksana RSUD X

\begin{tabular}{cccc}
\multicolumn{4}{c}{ Tahun $2017(\mathbf{n}=\mathbf{3 7})$} \\
\hline Variabel & Mean & SD & Minimal-Maksimal \\
\hline Umur & 33,89 & 4,63 & 28,46 \\
Lama Bekerja & 9,11 & 2,09 & \\
\hline
\end{tabular}

Berdasarkan Tabel 2. didapatkan rata-rata umur perawat pelaksana RSUD X adalah 33,89 tahun dengan standar deviasi 4,63 tahun dan rata-rata umur adalah diantara 28 tahun sampai 46 tahun. Sedangkan rata-rata lama bekerja adalah 9,11 tahun dengan standar deviasi 2,05 tahun dan rata-rata lama bekerja adalah diantara 5 tahun sampai 12 tahun.
Umur perawat pelaksana RSUD X Kota Bengkulu dengan rata-rata umur 33,89 tahun, dengan usia termuda 28 tahun dan usia tertua 46 tahun. Karakteristik dalam penelitian ini sejalan dengan penelitian Manulo (2015) bahwa lebih dari separuh usia perawat pelaksana di rawat inap RSUP Prof.Dr.R.D. Kandou manado $<36$ tahun $(75,67 \%)$. Sedangkan Maridi (2016) RSUD Sanggatta bahwa lebih dari 
separuh usia perawat, 30 tahun $(53,7 \%)$, namun penelitian Imran (2013) diketahui bahwa lebih dari separuh perawat pelaksana $>36$ tahun di RSUD Raden Matther Jambi. Intan (2016) umur bagi seorang pekerja akan mempengaruhi penerimaan beban kerja, seorang pekerja yang mempunyai umur relative muda mempunyai kemampuan lebih baik.

Lama bekerja perawat RSUD X Kota Bengkulu dengan rata-rata kerja 9,11 tahun dengan lama bekerja minimal 5 tahun maksimal 12 tahun. Sedangkan penelitian yang dilakukan oleh Maridi (2016) di RSUD Sanggatta diketahui bahwa lebih dari separuh perawat pelaksana memiliki masa kerja $>5$ tahun $(58,5 \%)$. Selanjutnya penelitian yang dilakukan oleh Manuho 92015) bahwa lebih adari separuh lama kerja perawat ruang rawat inap RSD Penambahan Senopan bantul $>5$ tahun $(74,6 \%)$. Masa kerja biasanya dikaitkan dengan waktu mulai kerja, dimana pengalaman kerja juga ikut menentukan kinerja seseorang. Semakin lama masa kerja kecakapan dalam menangani pasien akan lebih baik karena sudah menyesuaikan diri dengan pekerjaan.

Tabel 3. Distribusi Frekuensi Beban kerja Berdasarkan Karakteristik Perawat Pelaksana RSUD X Kota Bengkulu Tahun 2017 (n=37)

\begin{tabular}{|c|c|c|c|c|c|c|}
\hline \multirow{3}{*}{ No } & \multirow{3}{*}{ Karakteristik } & \multicolumn{4}{|c|}{ Beban Kerja } & \multirow{3}{*}{ Total } \\
\hline & & \multicolumn{2}{|c|}{ Produktif } & \multicolumn{2}{|c|}{ Tidak Produktif } & \\
\hline & & $\mathrm{F}$ & $\%$ & $\mathrm{f}$ & $\%$ & \\
\hline \multirow[t]{3}{*}{1} & Jenis Kelamin & & & & & \\
\hline & Perempuan & 20 & 83,3 & 4 & 16,7 & 24 \\
\hline & Laki-laki & 12 & 92,3 & 1 & 7,7 & 13 \\
\hline \multirow[t]{4}{*}{2} & Tingkat Pendidikan & & & & & \\
\hline & DIII Keperawatan & 8 & 80 & 2 & 20 & 10 \\
\hline & S1 Keperawatan & 20 & 87 & 3 & 13 & 23 \\
\hline & Profesi Ners & 4 & 100 & 0 & 0 & 4 \\
\hline \multirow[t]{3}{*}{3} & Status Kepegawaian & & & & & \\
\hline & PNS & 21 & 84 & 4 & 16 & 25 \\
\hline & Non-PNS & 11 & 91,6 & 1 & 8,4 & 12 \\
\hline
\end{tabular}

Berdasarkan Tabel 3. beban kerja perawat pelaksana berdasarkan karakteristik perawat pelaksana yang produktif adalah laki-laki 2 (92,3\%), perempuan $2(83,3 \%)$, pendidikan Ners 4 (100\%), S1 keperawatan 20 (87\%), DIII Keperawatan $8 \quad(80 \%)$ dan status kepegawaian Non PNS 11 (91,6\%), PNI $21(84 \%)$.

Beban kerja perawat pelaksana di RSUD X Kota Bengkulu berdasarkan jenis kelamin yang produktif adalah jenis kelamin laki-laki $12(92,3 \%)$ dan jenis kelamin perempuan $20(83,3 \%)$. Maridi (2016) RSUD Sanggata tenaga perawat produktif padaperempuan 25 (83,3\%), sedangkan laki-laki 5 (16,7\%). Penelitian Intan (2016) RS PKU Muhammadyah perawat produktif yaitu perempuan 52 (80\%) dan laki-laki $13(20,0 \%)$ produktif. Jenis kelemin tidak ada hubungan yang bermakna terhadap kinerja perawat pelaksana, hal tersebut dikarenakan dalam memberikan asuhan keperawatan tidak ada perbedaan gender, karena sejak masa pendidikan keperawatan baik perempuan maupun laki-laki mempunyai pengalaman belajar yang sama dalam mencapai kompetensi dan tujuan kurikulum pendidikan keperawatan. Dalam menjalankan tugasnya perawat perempuan dan laki-laki mempunyai tanggung jawab dan akontabilitas yang sama (hartati, 2012).

Beban kerja perawat pelaksana RSUD X Kota Bengkulu berdasarkan pendidikan dengan pendidikan Ners 4 (100\%) produktif, pendidikan S1 20 (87\%) produktif dan DIII $8(80 \%)$ produktif. Manuho (2015) RSUP Prof.Dr.R.D.Kanduo Manado, pendidikan S1 $(81,2 \%)$ produktif, Ners $(18,9 \%)$ produktif, dan DIII 6,2 \%) produktif. 
Menurut peneliti makin tinggi tingkat pendidikan perawat makan semakin meningkat produktif perawat tersebut.

Beban kerja perawat berdasarkan status kepegawaian perawat pelaksana RSUD X Kota Bengkulu dengan status
PNS $21(84 \%)$ produktif dan Non PNS 11 $(91,6 \%)$ produktif. Sedangkan penelitian yang dilakukan Ake (2014) RSUP RSUP Prof.Dr.R.D.Kanduo Manado PNS yang produktif $60(66,7 \%)$ dan Non PNS yang produktif $30(33,3 \%)$.

Tabel 4. Distribusi Frekuensi Beban Kerja Berdasarkan Ruang Rawat Inap RSUD X Kota Bengkulu Tahun $2017(\mathrm{n}=37)$

\begin{tabular}{|c|c|c|c|c|c|c|}
\hline \multirow{3}{*}{ No } & \multirow{3}{*}{ Ruang Rawat } & \multicolumn{4}{|c|}{ Beban Kerja } & \multirow{3}{*}{ Total } \\
\hline & & \multicolumn{2}{|c|}{ Produktif } & \multicolumn{2}{|c|}{ Tidak Produktif } & \\
\hline & & $\mathrm{f}$ & $\%$ & $\mathrm{f}$ & $\%$ & \\
\hline 1 & Melati & 16 & 88,9 & 2 & 11,1 & 18 \\
\hline 2 & Seruni & 16 & 84,2 & 3 & 15,8 & 19 \\
\hline
\end{tabular}

Berdasarkan Tabel 4. bahwa beban kerja perawat pelaksana ruang rawat melati produktif $16(88,9 \%)$ dan beban kerja perawat pelaksana ruang melati 16 $(84,2 \%)$. Beban kerja dalam penelitian ini terdiri dari beban kerja pada ruang rawat Melati (ruang rawat penyakit dalam) memiliki beban kerja produktif $16(88,9 \%)$ dan yang tidak produktif 2 (11,1\%). Sedangkan ruang rawat Seruni (ruang rawat bedah) dengan beban kerja produktif $16(84,2 \%)$ dan yang tidak produktif 3 $(15,8 \%)$.

Perawat yang bekerja di RSUD X Kota Bengkulu dengan sistem kerja shift malam selama 12 jam. Dalam penelitian ini ditemukan beban kerja produktif perawat pelaksana berdasarkan shift adalah shift pagi $100 \%$, shift sore $83,3 \%$ dan shif malam $66,7 \%$. Sedangkan penelitian Gian (2011) rumah sakit Muhammadyah bandung bahwa rata-rata penggunaan waktu produktif pada saat shift pagi $76,76 \%$, shift sore $71,56 \%$ dan malam 34,03\%. Ernawati (2011) rumah sakit umum Bali beban kerja perawat rata-rata penggunaan waktu produktif pada saat shift pagi $83,73 \%$, shift sore $80,80 \%$ dan shift malam 79,57\%. Warsito (2014) rumah sakit pemerintah bahwa rata-rata penggunaan waktu produktif pada shift pagi $90,70 \%$, shift sore $85,56 \%$ dan shift malam $84,13 \%$. Perawat yang dinas pagi mendapatkan beban kerja yang tinggi dari pada perawat yang berdinas sore dan malam. Tingginya beban kerja pada dinas pagi berhubungan dengan layanan tambahan dari rumah sakit berupa layanan terapi dan diagnostic yang diberikan dan jumlah pasien yang lebih banyak. Sedangkan pada malam hari para perawat lebih santai dalam bekerja karena jumlah kunjungan pasien relatif menurun (Gian, 2011).

Tabel 5. Distribusi Frekuensi Beban Kerja Berdasarkan Shift Perawat Pelaksana RSUD X Kota Bengkulu Tahun 2017 (n=37)

\begin{tabular}{|c|c|c|c|c|c|c|}
\hline \multirow{3}{*}{ No } & \multirow{3}{*}{ Shift } & \multicolumn{4}{|c|}{ Beban Kerja } & \multirow{3}{*}{ Total } \\
\hline & & \multicolumn{2}{|c|}{ Produktif } & \multicolumn{2}{|c|}{ Tidak Produktif } & \\
\hline & & $\mathrm{f}$ & $\%$ & $\mathrm{f}$ & $\%$ & \\
\hline 1 & Pagi & 13 & 100 & 0 & 0 & 13 \\
\hline 2 & Sore & 15 & 83,3 & 3 & 16,7 & 18 \\
\hline 3 & Malam & 4 & 66,7 & 2 & 33,3 & 6 \\
\hline
\end{tabular}

Berdasarkan Tabel 5. bahwa beban kerja perawat pelaksana berdasarkan shift waktu kerja adalah shift pagi produktif 13 $(100 \%)$, shift sore $15(83,3 \%)$ dan shift malam $4(66,7 \%)$. Beban kerja adalah seluruh kegiatan atau aktifitas yang dilakukan oleh seorang perawat selama bertugas di suatu unit pelayanan keperawatan (Marquis \& Huston, 2000). Beban kerja perawat pelaksana ada tiga 
jenis bentuk kegiatan antara lain kegiatan keperawatan langsung, kegiatan keperawatan tidak langsung dan pendidikan kesehatan (Gillies, 1996).

Efektifitas beban kerja perawat pelaksanan di instalasi rawat inap RSUD $\mathrm{X}$ Kota Bengkulu dengan rata-rata $87,43 \%$. Sedangkan efektifitas beban kerja perawat pelaksanan di ruang rawat melati $87,86 \%$ dan efektifitas beban kerja perawat pelaksana di ruang rawat seruni $87,02 \%$.

Beban kerja yang tinggi akan memberikan dampak terhadap kualitas layanan, terjadinya komunikasi yang buruk antar perawat dengan pasien, kegagalan kolaborasi antara perawat dan dokter, menimbulkan stress pada pekerja, kebosanan atau kejenuhan, kelelahan mental, dan menurunnya efektifitas kerja, penurunan tingkat kesehatan, penurunan kualitas pelayanan keperawatan, dan kegagalan melakukan tindakan pertolongan terhadap pasien dan dikatakan bahwa peningkatan beban kerja perawat dalam menangani 4 orang pasien menjadi 6 orang pasien mengakibatkan peningkatan sebesar $14 \%$ kemungkinan terjadi kelalaian atau bahkan kematian pasien yang dirawat (Yulmawati, 2012). Adapun dampak psikologis yang dirasakan akibat beban kerja yang tinggi adalah stress, ketegangan dan kebosanan atau kejenuhan dan ada pula perasaan jengkel.

\section{KESIMPULAN}

Berdasarkan hasil penelitian ini, maka kesimpulan yang didapatkan adalah sebagai berikut:

a. Karakteristik perawat pelaksana di RSUD X Kota Bengkulu adalah lebih dari separuh berjenis kelamin perempuan $(64,9 \%)$, lebih dari separuh berpendidikan S1 Keperawatan (62,2\%), lebih dari separuh denga status kepegawaian adalah PNS (67,6\%). Sedangkan rata-rata umur perawat pelaksana adalah 33,89 tahun dan ratarata lama bekerja adalah 9,11 tahun.

b. Waktu rata-rata keperawatan langsung perawat pelaksana di instalasi rawat inap RSUD X Kota Bengkulu 186,51 menit (3 jam 7 menit)

c. Waktu rata-rata keperawatan tidak langsung perawat pelaksana di instalasi rawat inap RSUD $X$ Kota Bengkulu 165,43 menit (2 jam 46 menit).

d. Waktu rata-rata pendidikan kesehatan perawat pelaksana di instalasi rawat inap RSUD X Kota Bengkulu 10,38 menit

e. Waktu rata-rata kegiatan pribadi perawat pelaksana RSUD X Kota Bengkulu 56,06 menit

f. Beban kerja perawat pelaksana RSUD X Kota Bengkulu tahun 2017 sebagian besar produktif sebanyak $86,5 \%$.

\section{SARAN}

a. Aplikatif Keperawatan

Menginat masih tingginya beban kerja perawat pelaksana pada shift pagi dan sore maka perlu dipertimbangkan pengelolaan tenaga perawat agar beban kerja perawat menjadi lebih seimbang.

b. Penelitian selanjutnya

Keterbatasan dari penelitian ini maka sebaiknya dilakukan penelitian lanjutan tentang analisis beban kerja perawat pelaksana dengan metode cohort studi dan tehnik Observasi. Wawancara dan Kuesioner untuk menilai mengumpulkan data tentang beban kerja perawat pelaksana di rawat inap dapat ditingkatkan.

\section{REFERENSI}

Agus Kuntoro, 2010. Buku Ajar Manajemen Keperawatan. Penerbit : Mulia Medika, Yogyakarta

Alghamdi, M.G. 2016. Nursing Workload: A Concept Analysis. Journal of Nursing

Management.10.1111.jonm.12354.

Association, Canadian Nurses. 2003. Measuring Nurses. Nursing Now, (15), 1-4.

Arwani. 2006. Manajemen Bangsal Keperawatan, Jakarta: EGC. 
A.Aziz Alimul Hidayat. 2014. Riset Keperawatan Dan Tehnik Penulisan Ilmiah. Yogyakarta: ISBN.

A.Aziz Alimul Hidayat. 2007. Metode Penelitian Keperawatan dan Tehnik Penulisan Data, Jakarta Selatan: ISBN.

Akde Triyoga. 2012. Kejenuhan Kerja (Bornout) Dengan Kinerja Perawat Dalam Pemberian Asuhan Keperawatan: Jurnal Stikes Volume 5, No 2.

Ake,D,I., Inap,R., Prof,C,R,Manado,R.D.K., Langingi,A,R,C,. kandou,G.D.,... Ratulangi,S. (n.d.). Hubungan Faktor Internal dan Eksternal Dengan Kinerja Perawat Pelaksana 10-1.

Brazilian. Bacterial Colonization Due To Increased Nurse Workload In An Intensive Care Unit.

Berry, L., \& Curry,P. 2012. Nursing Workload and Patient Care. Canadian Federation of Nurses Unian, (c), 1-98. Retrieved from.

Benedicta, T., Julianti,D., \& Eko, L. 2016. Produktivitas Petugas Unit Rekam Medis Rawat Jalan di Rumah Sakit.

Chie, H,H., \& Zuraida, R. 2013. Skala Pengukuran Shift Kerja, Beban Kerja, dan Persepsi Kesehatan Senagai Stressor Dengan Fasilitas manajemen Untuk Penanggulangannya. Inasea,14 (1), 15-21.

Di, P., Rawat, R., Medikal, I., RSUP, B., Kunci, K., \& Masalah, A. L. B. (2012) Hubungan beban kerja perawat dengan empati perawat di ruang rawat inap medikal bedah RSUP Dr. Soeradjitirto Negoro Klaten.

Depkes RI (2004) Surat Keputusan Menteri Kesehatan No.81/MENKES/SK/I/2004 Tentang penyusunan perencanaan Sumber Daya Manusia Kesehatan di tingkat Propinsi, Kabupaten/ Kota serta Rumah Sakit. Depkes RI, Jakarta.
Depkes RI (2010) Peraturan Menteri Kesehatan Republik Indonesia Nomor 340/MENKES/PER/III/2010.

Denise Neill. Nursing Workload and The Changing Health Care Environment : A Review Of The Literature. University of houston-Viktoria.

Dr. Jenita Doli Tine Donsu (2016) Metode Penelitian Keperawatan. ISBN 9786237-04-0.

Ernawati, N. L. A. K., Nursalam \& Djuari, L . (2011) Kebutuhan rill tenaga keperawatan dengan metode Workload indicator staff need (WISN). Jurnal Ners, 6,86-93.

Gillies.D.A.1996. Nursing Manajement A System Approach. Philadelphia. WB Saunders Company.

Gaudine (2000),

Measuring nurses'workload, CNA, Publications, nurses workload march 2003 e.pdf.

Dewi kartika (2013), Analisa jam perawatan langsung pada pasien bedah di ruang cendrawasih I : Universitas Riau.

Gian Nurmaindah H (2011) Gambaran beban kerja perawat pelaksana unit instalasi gawat darurat rumah sakit muhammadiyah bandung.

Imran, S. (2013) Hubungan karakteristik, beban kerja dan pertanggung jawaban /liability dengan motovasi perawat dalam pelaksanaan pendokumentasian asuhan keperawatan di RSUD Raden Mattaher Jambi tahun 2013 Jurnal Penelitian Universitas Jambi Seri Sains. Retrieved form id. Portalgaruda.org.

Intan Mayasari (2016) Hubungan beban kerja yang dilaksanakan perawat dengan kelengkapan dokumentasi asuhan keperawatan di ruang rawat inap RSPKU Muhammadiyah Yogyakarta : Journal Penelitian Universitas Aisyiyah Yogyakarta.

Ilyas, y, (2000) Perencanaan SDM Rumah Sakit :Teori, Metode dan Formula. Depok : FKMUI. 
Ilyas, y, (2004) Perencanaan SDM Rumah Sakit :Teori, Metode dan Formula. Depok : FKMUI.

Irwandy (2007) Faktor-faktor yang berhubungan dengan beban kerja di rawat inap.

Kemenkes RI (2012) Pedoman Tehnis Bangunan Rumah Sakit Ruang Rawat Inap.

Kurniadi, A. (2013) Manajemen Keperawatan dan Perspektifnya. FKUI : Jakarta

Kasmir (2016) Manajemen Sumber Daya Manusia Ed 1, Cat.2 Rajawali Pers : Jakarta.

Mediawati, Christine (2012) Analilis Beban Kerja Untuk Menentukan Kebutuhan Tenaga perawat. FKUI : Jakarta.

Marquis, B \& Huston (2000) Ledership Roles and Management Funcion in Nursing. Lippincott Company : Philadelphia.

Maridi M. Dirjo (2016) Hubungan antara dengan keinginan pindah kerja tenaga keperawatan di RSUD Sangatta. Jurnal Ilmu kesehatan Vol. 4 No. 2.

Makta, L., Noor, H. N. B., Sc, M., Kapalawi, I., \& Mars, M. S. P. H. (2013) Pengaruh Motivasi Kerja dengan Kinerja Perawat Pelaksana di Unit Rawat Inap RS Stella Maris Makasar.

Manuho, E., Warouw, H., \& Hamel, R (2015) Hubungan Beban Kerja Perawat dengan Kinerja Perawat dalam Pemberian Asuhan Keperawatan di Instalasi Rawat Inap CI RSUP Prof. DR. R. D. Kandou Manado. E-juornal Keperawatan 3 (2), 1-8.

Nursalam, Mnurs (2002) Manajemen Keperawatan Aplikasi dalam Praktek Keperawatan Profesional. Salembah Medika.

Nanang Martono (2010) Metodelogi Penelitian Kuantitatif: Analisis isi dan analisis data skunder/-ed-IRajawali Pers : Jakarta
Ni Luh Ade Kusuma. E. (2011) Kebutuhan Rill Tenaga Perawat dengan Metode Workload Indicator Stafe Need (WISN) RSUD Bali.

Pesant, G (2016) Balancing Nursing Workload by Constarint Programming Lecture Notes in Artificial Intelligence and lecture Notes in Bioinformatics. 9676 (section 2), 294-302.

Registered Nurse Assiciation of Onfario (2005) Nursing Workload Measurement Systems-A Discussion of the Issues. R1554_RNAO_Workload Measurement. Pdf.

Roymonndh, Simamora (2012). Manajemen keperawatan. EGC : Jakarta.

Saryono (2013) Metodelogi Penelitian Kualitatif dan Kuantitatif dalam Bidang Kesehatan. Yokyakarta. ISBN Statement. P (2015) $10.1177 / 1942602 \times 15594143$.

Suyato, Danag (2012) Manajmen Sumber daya Manusia. CAPS (Center For Aakademic Publishing Service) : Jakarta.

Sugiyono (2009) Penelitian Kualitatif dan Kuantitatif. Edisi 7. Mosby : Jakarta.

Siti Nurjannah (2017) Analysis Of Nurses Workload in Inpatient Care Installation of Regional Public Hospital (RHP) Of Kendaro City In 2016.

Sandra Aswar (2014) Faktor yang Mempengaruhi Efektifitas Pelaksanaan Pendokumentasian Asuhan Keperawatan di Insatlasi Rawat Inap Bedah Rumah Sakit Umum Daerah Andi Makkasau Parepare. Vol. 5 No. 4 ISSN: 23021721.

Tri hartati (2012) Program Orientasi dan Karatetistik dengan Kinerja Perawat Pelaksana di RS Roemani PKU Muhammadiyah Semarang. LPPM UNIMUS. ISBN : 978-18809-0-6.

Umansky, J., \&nRantanen, E, (2016) Workload in Nursing Proeeding of 
The human Factors and Ergonomics Society, 551-555.

Utami, Y, W, (n.d). Pendokumentasian Asuhan Keperawatan Ditinjau dari Beban Kerja Perawat, 7-12.

Warsito, B. E (2014). Shift kerja dan Rumah Sakit Pemerintah, I-12.

Widah, H., \& Yusuf, M.,(n.d) di Rumah Sakit Banda Aceh. Nursing Care Pratice of Nursing, 0-6
Wening Lasmito (2004) Motivasi Perawat Pendidikan Kesehatan di Ruang Anggrek RS Tugurejo Semarang. Jurnal UNDIP. 1-15.

Yulmawati. M. M. H. B (2012) Efektivitas Kerja Perawat di Insatalasi Rawat Inap RSU Mayjen H. A. Thalib Kabupaten Kerinci Provinsi Jambi. Jurnla Kesehatan masyarakat Vol. 6 No. 2 : 67-72. 